Original Research Paper

\title{
Pelatihan Tentang Penggunaan Ikan Sebagai Indikator dalam Menentukan Kualitas Air Sungai di Ampenan Tengah Mataram
}

\author{
Khairuddin $^{1 *}$, M. Yamin, dan' ${ }^{\text {, Abdul Syukur }}{ }^{1,2}$ \\ ${ }^{1}$ Program Studi Pendidikan Biologi Fakultas Keguruan dan Ilmu Pendidikan, Universitas Mataram \\ ${ }^{2}$ Program Studi Magister Pendidikan IPA, Pascasarjana Universitas Mataram
}

*Corresponding Author: Khairuddin, Program Studi Pendidikan Biologi Fakultas Keguruan dan Ilmu Pendidikan, Universitas Mataram, Indonesia;

Email:

khairuddin644@gmail.com

\begin{abstract}
Abstrak: Air adalah kebutuhan vital dalam kehidupan manusia. Hewan yang hidup di perairan sungai seperti ikan dapat menjadi indikator dalam penentuan kualitas air di sungai seperti sungai di Ampenan Tengah Mataram. Kegiatan pelatihan ini bertujuan untuk: 1) Melatih masyarakat sasaran di Ampenan Tengah untuk mengenal berbagai jenis ikan sebagai indikator biologi di Ampenan Tengah Mataram, 2) Memberikan pengetahuan tentang pengertian ikan sebagai parameter biologi pada masyarakar sasaran di Ampenan Tengah Mataram. 3) Memberikan contoh tentang cara menggunakan ikan dalam menentukan kualitasa air sungai di Ampenan Tengah Mataram dan 4) Pelaksanaan kegiatan ini menggunakan beberapa pendekatan dan metode adaah: 1) Pendekatan Sosial dan birokrasi, 2) Metode ceramah, 3) Metode demonstrasi dan praktek lapangan dan 4) Metode tanya jawab. Pelaksanaan Pelatihan menggunakan ikan sebagai indikator untuk menentukan Kualitas Air Sungai Di Ampenan. Jumlah peserta 20 orang dalam diskusi mereka cukup aktif. Dari hasil evaluasi $95 \%$ peserta dapat memahami dengan baik materi dan keterampilan dalam pelatihan. Kesimpulan dari kegiatan pengabdian ini telah dapat memberikan pemahaman tentang jenis-jenis ikan sebagai indikator penenuan kualias air. Selain itu peserta pelatihan telah memiliki keahlian dan keterampilan dalam menggunakan ikan sebagai indikator dalam menentukan kualitas air sungai dan dapat menerima informasi tentang pengetahuan dan perilaku yang dapat meredam terjadinya penurunan kualitas air sungai di kelurahan Ampenan Tengah dari para pelatih dari program studi pendidikan Biologi FKIP Universitas Mataram.
\end{abstract}

Kata Kunci: Ikan, Kualitas air sungai, Ampenan

\section{Pendahuluan}

Salah satu sungai besar yang melintas di kota Mataram adalah sungai Jangkok yang juga melintasi kelurahan Ampenan Tengah. Air sungai yang ada masih dimanfaatkan oleh masyarakat untuk berbagai keperluan seperti mandi dan mencuci, juga untuk perikanan dan fasiltas untuk pemeliharaan kankung. Kualitas air sangat penting untuk dikatehui oleh masyarakat di Kelurahan Ampenan Tengah, oleh karena kegiatan Pelatihan penggunaan ikan sebagai indikator dalam menentukan kualiras air sungai sangat penting untuk dilakukan.

Meningkatnya jumlah manusia akan menekan sumberdaya termasuk sumberdaya air seperti air sungai. Sungai merupakan sumberdaya yang dapat dimanfaatkan untuk berbagai keperluan manusia termasuk untuk transportasi dan pariwisata. Semakin intensifnya transportasi akan semakin intensif gangguan terhadap flora dan fauna di sungai termasuk ikan (Sukarsono, 2009; Maryono, 2007). Kualitas air sangat penting bagi manusia, karena setiap peruntukan air memerlukan persyaratan tersendiri baik untuk air mandi, bahan baku air minum ataupun untuk air perikanan. Kualitas air berhubungan dengan program kali bersih dari pemerintah kota Mataram saat ini. Air dapat dengan mudah tercemari oleh berbagai logam berat seperti timbal $(\mathrm{Pb})$, Tembaga $(\mathrm{Cu})$, dan merkuri (Hg) (Widowati, dkk, 2008).

Pencemaran merupakan hal senantiasa dihadapi manusia saat ini terutama pencemaran air. Pencemaran air dapat berasal dari sampah, limbah cair serta bahan pencemar lain seperti dari pupuk, 
pestisida, penggunaan detergen sebagai bahan pembersih, penggunaan bahan pembungkus yang menghasilkan banyak limbah dan sebagainya.

Hewan yang hidup di perairan sungai seperti ikan dapat menjadi indikator dalam penentuan kualitas air di sungai atau kali tersebut seperti yang ada di Ampenan Tengah Mataram. Manusia sedapat mungkin memelihara dan menjaga keberadaan lingkungan hidup di sekitar tempat tinggalnya. Lingkungan atau lingkungan hidup adalah kesatuan ruang dengan semua benda, daya, keadaan, dan makhluk hidup, termasuk manusia dan perilakunya yang mempengaruhi kelangsungan perikehidupan dan kesejahteraan manusia serta makhluk hidup lain (Anonim, 2000; Hadi. 2000, Soemantojo, 2004).

Air yang berkualitas baik adalah merupakan kebutuhan dasar manusia demikan juga dengan udara yang mengandung oksigen di dalamnya. Keberadaan air tidak saja ditentukan oleh jumlah tetapi juga mutu atau kualitasnya. Dalam kehidupan sehari-hari air yang berkualitas baik sangat menentukan kualitas kehidupan baik untuk manusia maupun makhluk hidup lainnya. Ikan dapat dijadikan indikator dalam menentukan kulaitas air (Tanjung, 2003). Kualitas air dapat ditentukan dengan berbagai parameter seperti parameter fisika, kimia dan biologi. Penentuan kualitas air sungai secara kimia dan fisika memerlukan waktu lama dan biaya yang besar, maka penggunaan parameter biologi dengan menggunakan ikan menjadi penting untuk dilakukan. Terdapat kriteria organisme yang dapat digunakan sebagai indikator biologi dengan memperhatikan faktor: 1 . Organisme harus sensitif terhadap material beracun dan perubahan linkungan, 2. Penyebanya luas dan mudah didapat dalam jumlah yang banyak, 3. Mempunyai arti ekonomi, rekreasi dan kepentingan ekologi baik secara daerah maupun nasional, 4. Mudah dipelihara dalam laboratorium, 5. Mempunyai kondisi yang baik, bebas dari penyakit dan parasite, 6. Sesuai untuk kepentingan uji hayati (Mason, 1991; Jeffrey, dan Maden, 1994; Loeb, dan Spacie, 1994).

Mengingat bahwa di daerah tropis sangat banyak keanekaragaman spesies ikan, maka sangat memungkinkan untuk menggunakan spesies-spesies yang beragam dalam menentukan kualitas air dari suatu badan air seperti sungai, danau ataupun bendungan. Penggunaan ikan sebagai indikator dapat dilakukan dengan metode Lucky yaitu dengan menghitung NVC (Nutrition value coefficient). NVC didapatkan dari berat ikan dalam gram dikali 100, dibagi panjang ikan dalam $\mathrm{cm}^{3}$. Kriteria kualitas air ditentukan dengan korelasi antara angka status nutrisi ikan (NVC) dengan tingkat pencemaran perairan seperti table 1 .

Tabel 1. Korelasi antara angka status nutrisi ikan (NVC) dengan tingkat pencemaran perairan.

\begin{tabular}{lll}
\hline No & NVC & Tingkat Pencemaran \\
\hline 1. & $\geq 1,70$ & Tidak ada, air bersih \\
2. & $1,30-1,69$ & Terkontaminasi \\
3. & $0,90-1,29$ & Tercemar ringan \\
4. & $0,50-0,89$ & Tercemar sedang \\
5. & $\leq 0,49$ & Tercemar berat \\
\hline
\end{tabular}

Sumber: Tanjung, 2003.

Selain itu ikan sebagai bioessay dapat digunakan untuk menguji adanya kandungan logam berat dalam air seperti Cadmium $(\mathrm{Cd})$, Timbal $(\mathrm{Pb})$, Mangan (Mn dan lainnya). Adanya timbal $(\mathrm{Pb})$ dapat menentukan bahwa ada pencemaran terhadap air tersebut sehingga mempengaruhi kualitasnya (Widowati, dkk, 2008).Banyak cara dalam memecahkan masalah lingkungan hidup yang perlu untuk dilakukan, kegiatan tersebut dapat dilakukan dengan membekali keterampilan pada masyarakat, penanaman kesadaran dan memberi pengetahuan dasar (Soedrajad, 1999; Wardhana, W.A, 1995).

Data pemantauan kualitas air yang dilakukan BLHP NTB pada 2010 di Sungai Jangkok yang merupakan sungai terbesar di Kota Mataram, kandungan "e-coli" mencapai 240.000 MPN (most probable number) per 100 mililiter atau jauh di atas standar baku mutu air kelas II sebesar 1.000 MPN/100 ml. Penelitian dilakukan termasuk di wilayah Kota Mataram yaitu dua wilayah tengah sungai dan dua wilayah hilir sungai jangkok di Kota Mataram (Badan Lingkungan Hidup dan Penelitian NTB, 2014). Dari informasi ini menunjukkan bahwa air di sungai jangkok di sekitar Ampenan Tengah telah mengalami pencemaran.

Masyarakat yang ada di Ampenan Tengah masih terbiasa memuang sampah dan air limbah di sungai sehingga mencemari perairan kali. Untuk menentukan kualitas air kali dengan menggunakan ikan sebagai parameter biologi, maka perlu dilakukan pelatihan pada masyarakat sehingga mampu mengukur dan menentukan kualitas air secara terus-menerus. Kegiatan pelatihan ini bertujuan untuk: 1) Melatih masyarakat sasaran di 
Ampenan Tengah untuk mengenal berbagai jenis ikan sebagai indikator biologi di Ampenan Tengah Mataram, 2) Memberikan pengetahuan tentang pengertian ikan sebagai parameter biologi pada masyarakar sasaran di Ampenan Tengah Mataram, 3) Memberikan contoh tentang cara menggunakan ikan dalam menentukan kualitasa air sungai di Ampenan Tengah Mataram, 4) Memberikan contoh perilaku yang dapat memeliharan lingkungan sekitar dan pengetahuan yang benar dalam kehidupan sehari-hari untuk meredam terjadinya perubahan kualitas lingkungan perairan sungai/kali di Ampenan Tengah Mataram.

Kegiatan ini dapat bermanfaat bagi peserta yaitu :1) Peningkatan pemahaman masyarakat sasaran untuk mengenal berbagai jenis ikan yang dapat dijadikan indikator kualitas air di Ampenan Tengah Mataram. 2) Peningkatan pemahaman yang benar tentang pengertian ikan sebagai indikator biologi pada masyarakat sasaran di Ampenan Tengah Mataram. 3) Peningkatan keterampilan tentang cara menggunakan ikan dalam menentukan kualitasa air sungai di Ampenan Tengah Mataram dan 4) Peningkatan perilaku yang dapat memeliharan lingkungan sekitar dengan aplikasi pengetahuan yang benar dalam kehidupan seharihari untuk meredam terjadinya perubahan kualitas lingkungan perairan sungai/kali di Ampenan Tengah Mataram.

\section{Metode Pelaksanaan}

Target luaran dalam kegiatan pelatihan ini adalah adalah adanya kemampuan bagi peserta pelatihan dengan sasaran 20 orang kader kelurahan Ampenan Tengah dalam menggunakan ikan sebagai indikator biologi dalam menentukan kualitas air sungai. Dalam pelaksanaan kegiatan ini menggunakan beberapa pendekatan dan metode yaitu: 1) Pendekatan Sosial dan birokrasi, dilakukan antara pihak petlatih dengan pihak kelurahan untuk mendaparkan peserta pelatihan dari kader terutama kader muda yang ada pada kelurahan Ampenan Tengah Mataram, 2) Metode ceramah, dimaksudkan untuk menjelaskan kepada peserta pelatihan tentang jenis-jenis ikan, ikan sebagai indicator biologi, jenis dan cara-cara penggunaan alat-alat untuk mengambil cuplikan atau sampel. Selain itu diberikan teknik-teknik pengambilan sampel, memberikan contoh-contoh perilaku yang perlu dilakukan untuk menjaga kualitas perairan sungai dan keselamatan kehidupan di perairan, yang dapat dilakukan secara individu maupun secara berkelompok oleh kader sasaran, 3) Metode demonstrasi dan praktek lapangan, untuk memberikan gambaran pada sasaran tentang cara menggunakan alat, cara mengidentifikasi sampel, cara mengklasifikasi sampel, cara menentukan kualitas air terutama dengan menggunakan ikan sebagai indikator kualitas air pada kader yang menjadi sasaran pelatihan, 4) Metode tanya jawab, digunakan untuk memberikan umpan balik pada peserta sekaligus untuk mendapat tanggapan peserta tentang materi kegiatan.

\section{Hasil dan Pembahasan}

Kegiatan Pelatihan tentang penggunaan ikan sebagai indikator dalam menentukan kualitas air sungai di Ampenan Tengah Mataram berlangsung dengan lancar dan aman bertempat di Aula Kantor Kelurahan Ampenan Tengah Kecamatan Ampenan Kota Mataram. Sejumlah 20 orang peserta sangat bersemangat dan antusias dalam diskusi, kegiatan kelompok dan disertai dengan kegiatan tanya jawab yang berhubungan dengan ikan sebagai indikator dalam menentukan kualitas air sungai selama pelatihan berlangsung. Pengetahuan, pemahaman dan keterampilan yang mendalam tentang pengukuran kualiras air dengan menggunakan ikan sebagai indikator adalah merupakan informasi yang sangat berharga bagi para peserta karena kegiatan serupa baru pertama kali terlaksana Kelurahan Ampenan Tengah Kota Mataram. Dari bimbingan pelatih peserta dapat mamanfaatkan formula perhitungan dalam pengukuran kualitas air dengan menggunakan ikan sebagai indikator untuk menentukan kualitas air sungai. Dari hasil penjelasan para pelatih, peserta memahami bahwa kualitas air yang baik penting bagi manusia karena setiap peruntukan air seperti untuk mandi, mencuci, dan sumber air minum menpunyai parameter sendiri-sendiri (Khairuddin etal., 2016). Pemahaman peserta terhadap materi pelatihan dapat dikatakan dipahami dengan baik. Sekitar 95 $\%$ peserta terlibat aktif dan memahami materi yang diberikan dalam pelatihan.

Wardhana (2001) menyaakan komponen pencemaran air dapat dikelompokkan sebagai 
bahan buangan 1) Padat 2) Organik 3) Anorganik 4) Olahan bahan makanan 5). Cairan berminyak 6). Zat kimia dan 7) Berupa panas. Air yang ada di sungai menerima hampir semuua jenis bahan buangan ini baik berupa zat padat, organik, anorganik, cairan berminyak dan lain-lainnya. Lingkungan perairan dapat juga terkontaminasi oleh Escherichia coli atau sejenis pencemar lain seperti bahan-bahan kimia. Soedradjat (1999), pernah melaporkan bahwa di sungai Bedadung Jember pernah terkintaminsi E.coli dari 4.000/100 ml sampai 90.000/ $100 \mathrm{ml}$ sample. Setiap spesies mempunyai niche sendiri-sendiri, sehingga setiap dimensi dari hipervolume untuk semua indikator ekologi berkecenderungan dengan kemampuan spesies untuk hidup dan memperbanyak diri atau reproduksi.

Ikan dapat menunjukkan reaksi terhadap perubahan fisik air maupun terhadap adanya senyawa pencemar yang terlarut dalam batas konsentrasi tertentu. Reaksi ini dapat ditunjukkan dalam percobaan di laboratorim, di mana terjadi perubahan aktivitas pernafasan yang besarnya perobahan diukur atas dasar irama membuka dan menutupnya rongga "Buccal" dan operculum. Sebagai indikator dari toxicant sub lethal juga dapat dilihat dari frekwensi bentuk ikan, yang dapat digunakan untuk membersihkan pembalikan aliran air pada insang, yang merupakan monitoring pergerakan respiratory (Anderson dan Apolonia, 1978 dalam Cahaya, 2014). Perubahan faal darah ikan yang diakibatkan senyawa pencemar, akan timbul sebelum terjadinya kematian. Pemeriksaan darah mempunyai kegunaan dalam menentukan adanya gangguan fisiologis tertentu dari ikan sehingga menentukan pertumbuhan ikan. Panjang dan berat ikan dapat menjadi indikator dalam menentukan kualitas air sungai. Parameter faal darah dapat diukur dengan mengamati kadar hemoglobin, nilai hematokrit dan jumlah sel darah merah. Ikan mas (Cyprinus Carpio L.) dapat digunakan sebagai salah satu hewan uji hayati dalam menentukan kualitas air sungai (Cahaya, 2014)

\section{Kesimpulan}

Berdasarkan pada hasil dan proses pelaksanaan kegiata pengabdian ini, dapat disimpulkan bahwa 1) Upaya pemeliharaan kesehatan masyarakat saat ini merupakan hal yang perlu mendapat perhatian yang sangat penting oleh pemerintah. Hal ini dikarenakan asupan makanan yang dikonsumsi kurang bergizi dan rendahnya daya beli masyarakat termasuk minimnya ketersediaan bahan pangan serta kurangnya pengetahuan masyarakat tentang pentingnya untuk menjaga kesehatan sejak dini hingga masa tua. 2) Kegiatan pengabdian gemar makan ikan bagi guru-guru sangat bermanfaat, dan masih sangat dibutuhkan. Mengingat kegiatan ini adalah kegiatan pertama di SMPN 2 Gunungsari, sehingga sangat wajar respon guru-guru sebagai khalayak sasaran mendaptkan apresiaisi yang tinggi

\section{Saran}

Dari pengalaman yang diperoleh selama proses kegiatan pengabdian dilakukan, anggota tim menyarankan: 1) Semua pihak terkait, terutama perguruan tinggi melalui Lembaga penelitian dan Lembaga Pengabdian Kepada Masyarakat perlu melakukan penelitian dan pemberdayaan masyarakat dengan program Gemar makan ikan sejak zama orde baru sampai saat ini. 2) Dinas pendidikan kabupaten harus menjalin kerjasama yang baik dan berkelanjutan dengan Dinas kelautan dan Perikanan, dan Dinas Kesehatan untuk dapat membuat dan melaksanakan program pemberdayaan dan sosialisasi gemar makan melalui sekolah, sehingga nantinya program ini dapat meningkatkan derajat kesehatan masyarakat khususnya guru dan siswa.

\section{Daftar Pustaka}

Anonim, 2000. Undang-undang Republik Indonesia Nomor 23 Tahun 1997 Tentang Pengelolaan Lingkungan hidup. Himpunan Peraturan Tentang Pengendalian Dampak Lingkungan. Bapedalda NTB. Mataram

Hadi, S.P, 2000. Manusia dan Lingkungan. Badan Penerbit Universitas Diponegoro, Semarang.

Cahaya, Indra. 2014. Ikan Sebagai Alat Monitor Pencemaran. Tersedia. Online. http://mspuh.wordpress.com/2010/07/07 
likan-sebagai-alat-monitor-pencemaran/, 2014). diakses 12 Maret 2014.

Badan Lingkungan Hidup dan Penelitian NTB. 2014. Kualitas Air Sungai Mataram Makin Parah. http://sumbawabaratnews.com, diakses 12 Maret 2014

Khairuddin, Yamin, M dan Syukur, A. 2016. Analisis kualitas air kali Ancar dengan menggunakan Makroinvertebrata. Jurnal Biologi Tropis, Volume 16 (2) : $10-22$.

Jeffrey, D.W; dan Maden, B, 1994. Bioindicator and Environmental Management. Academic Press Limited. London.

Loeb, S.L. dan Spacie, A. 1994. Biological Monitoring of Aquatuic System. Lewis Publishers. Florida, United States of America.

Mason, C.F. 1991. Biology of Freshwater Pollution. Longman Group. United Kingdom.

Maryono, 2007. Restorasi Sungai. Gadjah Mada University Presss. Yogjakarta.

Soedradjad, R, 1999. Lingkungan Hidup. Ditjen Dikti, Dekdikbud, Jakarta.

Soemantojo. 2004. Pendidikan dan Etika Lingkungan Hidup. Jurnal Lingkungan dan Pembangunan. Volume 24 Nomor 1: 23.

Sukarsono, 2009. Ekologi Hewan. UMM Press, Malang.

Tanjung, S.D. 2003. Ilmu Lingkungan. Laboratorium Ekologi, Fakultas Biologi, Universitas Gadjah Mada. Yogjakarta.

Widowati, W; Sastiono, A; dan Yusuf, R.2008. Efek Toksik Logam. Andi, Yogjakarta.

Soedradjad, R, 1999. Lingkungan Hidup. Ditjen Dikti, Dekdikbud, Jakarta.

Wardhana, W.A, 1995. Dampak Pencemaran Lingkungan. Andi Offset, Jakarta.

Wardhana, W.A, 2001. Dampak Pencemaran Lingkungan. Andi, Yogjakarta. 